\title{
Farmers' Willingness to Adopt Short Rotation Plantations on Marginal Lands: Qualitative Study About Incentives and Barriers in Slovakia
}

\author{
Lea Ranacher ${ }^{1,2}$ (D) Barbora Pollakova ${ }^{1} \cdot$ Peter Schwarzbauer $^{2} \cdot$ Sandra Liebal $^{3} \cdot$ Norbert Weber $^{3}$ - Franziska Hesser ${ }^{1}$
}

Received: 22 June 2020 / Accepted: 17 December 2020 / Published online: 21 January 2021

(C) The Author(s) 2021

\begin{abstract}
Short rotation plantations (SRP), also called short rotation coppice, can contribute to bioeconomy by satisfying the rising demand for wood raw material while strengthening the rural economy. However, farmers all over Europe show limited adoption of SRP. Marginal lands are considered a promising option for producing SRP biomass and avoiding conflicts with food production. This study focuses on the Malacky region in Western Slovakia because of suitable land quality and a board production site close by providing a significant local market for the produced biomass. Qualitative interviews in 2018 explored personal and situational factors that influenced local farmers' $(N=19)$ willingness to adopt SRP. Slovakia's land fragmentation in combination with the required landowner's consent, competition with food production, and lack of identification with SRP were identified as prominent barriers. The economic benefit from using low quality lands and environmental benefits from SRP were identified incentives. Moreover, the study found agricultural cooperatives more open to SRP than agricultural business companies, as they are more interested in the economic benefits and prefer agricultural activity over fallow land. Because the study identified conflicting views about the possible impacts of SRP on the environment and the rural community, it is considered crucial to provide farmers with science-based facts on these issues. This aspect should also be acknowledged to increase acceptance of stakeholders, such as land owners, governmental actors, and the general public, which is needed to develop measures to encourage SRP.
\end{abstract}

Keywords Farm diversification · Adoption of innovation $\cdot$ Land use change $\cdot$ Short-rotation coppice $\cdot$ Perception

\section{Introduction}

The transition from using nonrenewable resources to renewable resources for energy and material is gaining momentum with the political-economic concept of a bioeconomy $[1,2]$. With the new bio economy strategy for Europe, it is aimed to reduce greenhouse gas emissions, provide sustainably produced food and energy, and implement a circular, secure, and resource-efficient economy [3]. The forest-based sector has the potential to take a

Lea Ranacher

1.ranacher@wood-kplus.at

1 Competence Center for Wood Composites and Wood Chemistry, Kompetenzzentrum Holz GmbH, Altenberger Straße 69, 4040 Linz, Austria

2 Department of Economics and Social Sciences, Institute of Marketing and Innovation, University of Natural Resources and Life Sciences Vienna (BOKU), Feistmantelstaße 4, 1180 Vienna, Austria

3 Forest Policy and Resource Economics, Technical University Dresden, Pienner Straße 23, 01735 Tharandt, Germany central role in bioeconomy by providing considerable amounts of raw materials and products [4]. However, forestry alone is not able to meet the growing demand of woody biomass for all material and energy needs, due to technical constraints, as well as ecological and legal restrictions, such as processing technologies, forest conservation, and sustainable forest management practices, respectively [5]. Short rotation plantation (SRP) is a cultivation form in which fast-growing tree species are grown on agricultural land. This is considered a viable option to feed the increasing demand for lignocellulosic material [6-8]. Moreover, research findings show the best possible energy-input to energyoutput ratio [9] in agricultural cultivations and positive environmental effects of SRP $[10,11]$. The positive environmental impacts comprise phytoremediation, preventing and managing soil erosion [12], water purification via nutrient buffering [13], increasing biodiversity, and soil diversity [14]. In addition, the establishment of SRP can contribute to the European Commission's goals of the Common Agricultural Policy reform of sustainable land use (such as the green direct payment scheme; "Greening"), sustainability of agriculture, diversification of the crops composition, and preservation of the environment $[14,15]$. 
In the context of "Greening" in a broader sense, SRP can be an option to contribute to the recently identified global tree restoration potential of 0.9 billion hectares to mitigate climate change $[16,17]$.

To avoid competition with food and feed production, marginal or currently unused land (i.e., fallow land) can be a promising option for SRP. Marginal land is a land of poorer soil fertility, lower agricultural value and therefore also mostly less profitable for annual crop production [18]. Thus, SRP on marginal or unused land represents an economically interesting option for its owners because they can obtain high and stable yields despite poor soil quality [19]. Growing SRP on marginal lands in rural, low-income regions can contribute to value creation in rural communities by producing and providing biomass that feeds into existing and new wood value chains and at least partly by creating jobs for the rural population. In this context, SRP are an on-farm diversification activity, entailing the development, transfer and use of new technologies, as well as the exploration of marketing and other process innovations in pursuit of value creation [20]. In Eastern Europe, an abundance of rural land is often subject to land abandonment and therefore considered suitable for SRP [21].

Despite the proclaimed benefits to the environment and rural communities, such as additional income, farm diversification and low labor input, there are currently approximately 50,000 ha of SRP in Europe [7]. The attention to social and political factors might identify issues that can be addressed in advance by technology developers, and the new technology can avoid an obstacle that would threaten the economic viability of the technology [22]. In this context, there are three challenges linked to a large-scale implementation of SRP, which can be summarized as "need for societal acceptance" or "social license to operate," an issue that is often brought up in bioeconomy and renewable energy related research [23, 24]. First, information regarding the perception of woody biomass production by stakeholders is essential in order to create opportunities for value creation, i.e., make an investment in SRP fed value chains in rural areas. Second, farmers' willingness to adopt SRP is a prerequisite to the security of raw material supply and with that to the economic sustainability of the manufacturing operations. Third, the local population and the general public need to accept the resulting land use change.

In this context, a study [25] shows that the local population clearly differentiates in their level of acceptance between traditional and non-traditional land uses (e.g., plantation vs. food production). From a farmer's perspective, high investment costs, long lasting binding of sites and capital, low prices for SRP biomass [26], as well as limited identification with SRP related to farmers' socio-cultural identity [27] are reported as prominent barriers in literature, whereas low site requirements [28] and income opportunity [7] were reported as incentives.
In a review [29], scholars argue that it is not possible to decide on universal influencing factors for the acceptance of land-use management practises because these factors differ between cases and depend on the theoretical framework of each study. Several studies show that farmers' willingness to adopt SRP is limited and little is known about the situation for marginal lands [19, 30, 31].

Reviewing the literature, there is a gap regarding farmers' willingness to adopt SRP on marginal lands. In addition, studies often focused on energy use and were mostly from Western and Northern Europe [31-34], whereas countries in Eastern Europe have received minimal attention to date. To address this gap, we investigate factors influencing farmers' willingness to adopt SRP on their marginal land. We start out from Ajzen and Fishbein's theory that that a certain behavior depends on the person's own attitude toward the behavior, the social norms in the social setting, as well external conditions $[35,36]$. Thus, the research question is the following:

Which Factors Influence Famers' Willingness to Adopt SRP on Marginal Lands and How? On a scientific level, this study will contribute to the growing body of literature about farmers' willingness to adopt SRP and specifically address the gap related to marginal lands. On a practitioner level (e.g., policy and industry), it will unfold incentives and barriers for the establishment of SRP on marginal lands, which can be addressed in future supporting measures.

\section{Incentives and Barriers Relevant to the Adoption of SRP}

This section is intended to report on the state of knowledge of factors influencing farmers' willingness to adopt SRP as a basis for the empirical research. Factors that positively influence farmers decision are referred to as incentives, and those negatively influencing their decision are referred to as barriers. An overview about identified factors differentiated into incentives and barriers is given in Table 1. Due to the limited literature regarding marginal lands, we do not differentiate between "normal" agricultural land and marginal land.

A German study [41] found several factors relevant to the adoption of SRP such as economic aspects, law and politics, agricultural land and available technologies, company goals, experience, and personal reasons and feelings. Incentives for SRP refer to employment opportunities [7] and access to attractive new markets (e.g., energy, material) for small-scale suppliers [37]. Subsidies, e.g., for non-market eco-system services, establishment grants or loans can serve as incentives to increase the willingness of farmers to invest in SRP or bioenergy plants [39]. In a scenario analysis evaluating the performance of a range of policy instruments, an establishment subsidy was found to have the greatest effect on the 
Table 1 Incentives and barriers for the adoption of SRP derived from literature review (exemplary references are indicated in the table)

\begin{tabular}{ll}
\hline Incentives & Barriers \\
\hline Employment opportunity [7] & $\begin{array}{c}\text { Financial risk such as high investment costs, long } \\
\text { periods without financial return, uncertain }\end{array}$ \\
& $\begin{array}{r}\text { returns due to price volatility) [7] } \\
\text { Lack of skills and infrastructure [33] }\end{array}$ \\
Low labor input [37] & Uneconomic yields [26] \\
Low site requirements [28] & Prioritization of food production [38] \\
Farm diversification [7] & Degradation of soil [40] \\
Funding programs for establishment [39] & Long-term commitment [32] \\
Attractive new markets and infrastructure [37] & High investment costs [26] \\
Environmental benefits (e.g., phytoremediation) [37] & Socio-cultural identity [27] \\
& Unfavorable legal framework conditions [7] \\
& Lack of tradition [2] \\
& Land availability [21, 39]
\end{tabular}

adoption of SRP and farm income [42]. Moreover, infrastructure and major facilities of utilization are important factors in decision making among farmers [39]. Other incentives are the low labor input activity [37], the option of farm diversification [7], and use of low quality soils due to lower site requirements [28]. Positive environmental impacts (e.g., phytoremediation) were also found to serve as an incentive for farmers as well as the commitment of land for a long time period [37]. At the same time, the long-term commitment of land was found to serve as a barrier as well [32].

Barriers for the engagement in SRP can be roughly divided into financial and non-financial reasons. Missing or unfavorable legal framework conditions, as well as various technical and non-technical barriers [7] are examples for non-financial barriers. With regard to financial barriers, SRP can provide access to attractive new markets (e.g., energy, material use). Literature argues that SRP yields are not yet economically viable as a result of high investment costs [26] combined with uncertain returns on investment due to price volatility [43].

Farmers perceive SRP as a financially risky crop requiring long-term commitment [27]. In the United Kingdom, the investment risk for farmers constitutes a major barrier, as under existing economic conditions, most farmers do not make any profit until they have sold their crop in year 10 after making costly investments [32]. However, this aspect may not be of relevance for forest owners, who are used to long-term commitment. In addition, if there are only few SRP farmers, infrastructure is not yet sufficient to support the development of the supply chain to a point where economies of scale can be achieved [32, 44]. Furthermore, the issue of land availability $[21,39]$ is raised, as farmers would need a lot more land at appropriate land costs to adopt the practice.

For bioenergy production in Great Britain, the estimated crop margins from SRP willow are lower than from wheat [2], resulting that competing activities are more financially attractive to farmers. In this context, farmers pointed out that low-quality land (i.e., marginal land) could be used for SRP instead. However, marginal lands while being physically abundant, may not be available because of opportunity costs associated with existing activities, the riskiness and costly reversibility of investments, and possible disamenities from changed land use [31].

Even though financial aspects are important to farmers, the decision for a type of agricultural production rather is about profit sufficiency than profit maximization [2]. The reason is that farmers see farming as their vocation and are not interested in a change of current farming methods that is not part of a tradition [2]. In this context, a study [27] found that sociocultural identity is more important than economic reasons to engage in SRP. Socio-cultural identity is a person's selfconception and self-perception as part of a social group that has its own distinct culture. Considering this, SRP does not contribute to socio-culturally relevant factors such as identity and farming lifestyle [27].

Another prominent barrier to SRP is farmers' prioritization of food production and negative sentiments toward non-food agricultural activities such as growing bioenergy crops, also known as the "food versus fuel" debate [38].

The adoption of agricultural practices that are new to a farming community can be influenced by a "follow the leader" mentality, which means that one farmer needs to engage in a new agricultural activity and only afterward will be followed by the exact same action of others [2]. This can be related to a persons' limited innovativeness and "passive farming" [20]. In this context, the lack of experience or lack of tradition with SRP, resulting in a lack of skills and expertise among farmers [33], constitutes a barrier. In Germany, farmers regard the process to switch from common crops to SRP as too complex, due to the different cultivation methods for growing, harvesting, and tilling, as well as suitable species selection [32]. For 
example, in Latvia, farmers reported difficulties related to ineffective weed control measures [39]. Even though environmental benefits (e.g., phytoremediation) can serve as incentives, farmers are concerned about soil degradation due to continuous removal of large amounts of produced SRP biomass $[40,45]$.

In addition, the characteristics of contracting agreements with biomass buyers are an important factor, but have been minimally studied. The level of net returns above the next best alternative land-use (i.e., opportunity costs), contract length, having a biorefinery harvest option, availability of insurance, and having monetary incentives/cost share are important contract attributes [46]. The literature shows that next to situational factors such as market conditions, personal factors such as personal values related to farming and land play a role. In addition, there do not seem to be consistent linkages between farmer objectives, behaviors, characteristics or farm physical features and willingness to grow energy crops evident from the literature [37].

\section{Material \& Methods}

\section{Conceptual Background}

This explorative study refers to farmers willingness to adopt SRP, considering the farmers as entrepreneurs who decide to invest their assets, i.e., their land and labor, in a new agricultural practice and thereby adopt a new production system. Acknowledging the challenges in considering farmers as entrepreneurs, the adoption of innovation in search of diversified farm business opportunities is consistent with wider conceptions of entrepreneurship [20]. Innovation diffusion theory has become popular to analyze farmers' response to new policy initiatives, analyzing it by the key characteristics of innovation [27]. Several studies investigated farmers' willingness to adopt new farming practices [47], new production systems for farm diversification (such as SRP) [27, 39], or practices to generate off-farm income [20], to name only a few. For the case of bioenergy crops, farmers' attitude and perceived difficulty to engage in a new production system were identified as relevant factors [20]. Thus, the interviewed farmers can be considered as early adopters in the process of innovation diffusion [48].

The aim of the study is not to investigate the final outcome such as the level of willingness to adopt SRP of a larger group, but to identify and describe the factors that influence farmers' willingness to adopt SRP (i.e., decision for land use change). To identify the factors, we refer to farmers' motivation. The motivation of a person to act a certain way is shaped by the interaction of personal and situational factors [49]. Personal and situational factors can also be referred to as internal and external factors. Personal factors consist of universal behavioral tendencies and needs, implicit motives, and explicit motives, whereas situational factors consist of intrinsic and extrinsic incentives [49]. The model considers external and structural conditions as "situational factors," which are particularly relevant for the acceptance of a new agricultural production system because these context-specific factors are related to the geographic location and production system. In contrast, the technology acceptance framework [50], often used for technology acceptance studies, does not contain context-specific factors related to the geographic location.

\section{Description of the Case Study}

The study investigates the incentives and barriers to engage in SRP through qualitative interviews with farmers in the Zahorie region in Eastern Slovakia. The Zahorie region was selected for two reasons. First, because SRP poplar is the woody biomass crop best matched to the biophysical conditions in this region. Second, an important particle board production site is located in Malacky, representing a significant local market for woody biomass from SRP poplar. The company aims to source $30 \%$ of their wood demand from local SRP grown within a $100 \mathrm{~km}$ radius, representing a valuable alternative market for local farmers and thereby contributing to rural development.

Slovak agriculture is considered to be of low efficiency with a low level of added value [51]. Of traditional agricultural landscapes in Slovakia, 50\% are abandoned or partly abandoned and can be characterized as marginal since their soil fertility is low [52]. The most present legal forms of Slovak farms are agricultural business companies and agricultural cooperatives, whereas agricultural business companies farm $42.9 \%$ and agricultural cooperatives farm $35.6 \%$ of the utilized agricultural land according to the Green Report [53]. Agricultural cooperatives have maintained a dominant position in Slovakia even after the Velvet Revolution of 1989 that was followed by the transition from the socialist planned economy to a market economy. One of the reasons that this legal entity remains dominant is Slovakia's land fragmentation complicating its legal transformation into an agricultural business company. Agricultural business companies demonstrate higher economic performance and efficiency when compared to agricultural cooperatives [54].

Further important aspects in respect to the agricultural structure are the land ownership structure and related land fragmentation. Due to the collectivization of agricultural land in 1948, property rights were neglected under socialist planning [55]. After the Velvet Revolution, the property rights were restored leading to multiple owners for a parcel of land. In other countries, such as the Czech Republic, agricultural land was usually inherited by one inheritor only [56]. As this was not the case in Slovakia, the agricultural land ownership is scattered. Slovak agricultural land covers approximately $50 \%$ of the whole area and consists of a small-block mosaic 
agricultural landscape [55]. This results in problems concerning leasing and purchasing of land, especially because there were identified 9.6 million plots with an average size of 0.45 ha owned by $12-15$ persons [56]. Approximately $20 \%$ of the agricultural land belongs to unknown owners [57].

Approximately $90 \%$ of the total utilized agricultural area in Slovakia is leased, and only $10 \%$ of the cultivated land is managed by farmers owning their land [53]. The church, private entities, state and military, and municipality represent the major land owners in Slovakia. According to Slovak Law 220/2004 about protection and use of agricultural land, the land owners' consent is required prior to planting of SRP. The land owner needs to sign the agreement for SRP and only afterward the farmer is allowed to grow SRP.

In Slovakia, there is an agricultural land potential for SRP of approximately 23,000 ha [58] acknowledging the legal restriction of SRP to the "low quality" soil classes 5-9. Potential land for SRP was selected by the following criteria: First, soil quality classes 5-9 were targeted because they are considered marginal. Second, Slovakia's land ownership structure is highly scattered, suitable parcels should not have more than four individual land owners, as the land cannot be efficiently managed when there are more owners. Third, to allow regional value creation, the parcels have to be close to the particle board production site (within an approx. $100 \mathrm{~km}$ radius). Fourth, the parcels have to be outside of nature conservation areas and without any other environmental value, such as marsh areas. Based on these criteria, there are 23,000 ha theoretically available and only those parcels were selected on which SRP would lead to an improvement of the agricultural site [58].

Suitable marginal lands are currently used for agricultural production or unused, i.e., lays fallow. SRP poplar differs from the current agricultural production practices, notably because of its visual appearance, greater rooting depths, perennial nature, weeding measures, and harvesting cycle (in the 5 th year in winter). Usually, planting SRP requires different expertise, skills, and machinery compared to current agricultural practices.

However, to incentivize farmers for SRP production, the local panel industry offers contracts to farmers taking over the planting, the weeding in the first year, as well as the harvesting. With harvesting and transport constituting the biggest share of the overall cultivation costs [33], this procedure is taking the burden off of farmers to make investments in machinery or skills to grow SRP.

\section{Data Collection \& Analysis}

Semi-structured interviews in the form of face-to-face interviews were conducted. This qualitative method places the interviewed person at the center of attention and allows flexibility to encompass individual cases [59]. The motivation and action model [49] was used to develop the interview guideline to identify and describe personal and situational factors. Attitudes and values related to farming and agricultural land or making a living in general are refered to as personal factors. Situational factors are related to policy frameworks, support systems, regulation, legal situation, subsidies, and market situation. A situational factor, for example, is related to little financial gains and high investment costs, whereas a personal factor is a lack of personal identification with SRP.

The interviews were conducted with the help of a semistructured questionnaire that consisted of two parts. The first part contained questions on the farm manager and details on his/her farm as well as the relationship to the land. The second part contained questions on the perception of their experience with SRP. The questions of the interview are summarized in Table 2. In total, 19 farmers were interviewed, of which nine farmers were not engaged in SRP and ten farmers were engaged in SRP. The contacts to the farmers fulfilling the abovementioned criteria (see "Description of the case study") were established via the land acquisition tasks conducted within the project Dendromass 4 Europe [58].

Listed farmers (25 not engaged and 14 engaged in SRP) were contacted by phone. Those willing to participate in the study were visited personally on their farms, where interviews were conducted from January to March 2018. The interviews took $30-100 \mathrm{~min}$ and were recorded. The first group of interviewed farmers were already engaged in SRP activities (ten farmers), while the second group consisted of farmers not engaged in SRP (nine farmers). The majority of interviewed farmers manage mostly leased land, owned by the church, municipality, state and military, as well as private persons. Usually farmers manage $20 \%$ state owned land, which aimed to grow SRP. The interviewed farmers are described in Tables 3 and 4 by their main characteristics. Classic crop production in Slovakia consist mainly of cereals. Winter wheat, spring barley, and maize cover $59 \%$ of the agricultural land [60].

After the interviews were completed, they were transcribed and analyzed with the statistics software MAXQDA, where a code system was built to group the information collected in the interviews for the qualitative content analysis. The code system was built from a combination of a deductive and inductive approach. First, condensed meaning units were created. Second, codes were built, and finally the codes were grouped into a category system. Deductive coding followed the description of incentives and barriers found in the literature and the differentiation between personal and situational factors [49], as depicted in Table 5. The results presented in the "Results" section pertain to both groups $(N=19)$, unless otherwise stated. 
Table 2 Key questions of the interview guideline

\begin{tabular}{ll}
\hline Topics & Key questions (examples) \\
\hline $\begin{array}{l}\text { Socio-demographic and farm } \\
\text { type information }\end{array}$ & Age, education, size of farm, type of farm, land ownership \\
$\begin{array}{l}\text { Relationship to land and land } \\
\text { activities }\end{array}$ & What does the land represent in your life? \\
Why did you become a farmer? \\
$\begin{array}{l}\text { Social environment } \\
\text { Perceptions of short rotation } \\
\text { plantations }\end{array}$ & $\begin{array}{l}\text { How do your family, friends, neighbors, etc., feel about your work? } \\
\text { Benefits, disadvantages \& } \\
\text { experience }\end{array}$ \\
$\begin{array}{c}\text { Have you heard about the benefits and disadvantages that short rotation } \\
\text { plantation offers? }\end{array}$ \\
What are the reasons (not) to grow short rotation plantations? \\
Which constraints did/would you experience when growing short rotation \\
plantations?
\end{tabular}

\section{Results}

\section{Personal Factors Relevant for the Adoption of SRP}

Personal values, attitudes, self-images, and habits were identified as relevant factors and are described below. Table 6 provides an overview of the identified personal factors differentiating them into incentives and barriers.

We found that SRP was perceived to be both compatible and incompatible with farmers' values they hold toward farmed land. Several farmers, mostly of agricultural cooperatives, engaged in SRP because they want to use fallow land in a productive way. For them it is important that agricultural land is being used instead of lying fallow. They expressed their aversion toward mulching agricultural land once a year and making profits only by receiving subsidies: "This is not agriculture. It is a misuse of the system." Agricultural cooperatives disliked this behavior and felt responsible for the land, the people living in the rural areas, and the people working for them. One farmer mentioned that fallow land could even provide higher return in case the SRP yield will be lower as expected. Taking this risk suggests that he perceives SRP as a better alternative to fallow land.

Table 3 Description of farm and farmers characteristics engaged in short rotation plantations (SRP) $(n=10)$

\begin{tabular}{|c|c|c|c|c|c|c|}
\hline No & $\begin{array}{l}\text { Socio- } \\
\text { demographics }\end{array}$ & $\begin{array}{l}\text { Total size of farm } \\
\text { (ha) }\end{array}$ & $\begin{array}{l}\text { Size of } \\
\text { SRP } \\
\text { (ha) }\end{array}$ & Type of agricultural production & $\begin{array}{l}\text { Legal entity } \\
\& \text { ownership }\end{array}$ & Ownership \\
\hline 1 & Male, $>60$ & 99 & 27 & $\begin{array}{l}\text { Animal (mainly) and classic } \\
\text { crop production }\end{array}$ & $\mathrm{ABC}$ & $100 \%$ owned \\
\hline 2 & Male, $>60$ & 260 & 8 & Classic crop production & $\mathrm{ABC}$ & $100 \%$ owned \\
\hline 3 & Male, $<50$ & 650 & 150 & Forestry & $\begin{array}{l}\text { State \& military } \\
\text { organization }\end{array}$ & State owned \\
\hline 4 & Female, $>50$ & 830 & 30 & $\begin{array}{l}\text { Animal (mainly) and classic crop } \\
\text { production, } \\
\text { poppy seeds, wine }\end{array}$ & $\mathrm{AC}$ & Mostly leased \\
\hline 5 & Male, $>50$ & 1420 & 24 & $\begin{array}{l}\text { Classic crop production and animal } \\
\text { production }\end{array}$ & $\mathrm{AC}$ & Mostly leased \\
\hline 6 & Male, $<50$ & 2600 & 38 & Classic crop production & $\mathrm{ABC}$ (former $\mathrm{AC}$ ) & Mostly leased \\
\hline 7 & Male, $>50$ & 2600 & 30 & Classic crop production & $\mathrm{ABC}$ & Mostly leased \\
\hline 8 & Male, $>50$ & 4000 & 14 & Classic crop production & $\mathrm{ABC}$ & $\begin{array}{r}\text { mMostly } \\
\text { leased }\end{array}$ \\
\hline 9 & Female, $>50$ & 8200 & 30 & $\begin{array}{l}\text { Classic crop production and animal } \\
\text { production, organic production } \\
\text { on } 50 \% \text { of agricultural land }\end{array}$ & $\mathrm{ABC}$ & Mostly leased \\
\hline 10 & Male, $<50$ & 9300 & 27 & $\begin{array}{l}\text { Classic crop production and animal } \\
\text { production }\end{array}$ & $\mathrm{ABC}$ & Mostly leased \\
\hline
\end{tabular}

$A B C$ agricultural business companies, $A C$ agricultural cooperatives 
Table 4 Description of farm and farmers characteristics interviewed but not engaged in short rotation plantations $(n=8)$

\begin{tabular}{|c|c|c|c|c|c|}
\hline No & $\begin{array}{l}\text { Socio- } \\
\text { demographics }\end{array}$ & $\begin{array}{l}\text { Total size of } \\
\text { farm (ha) }\end{array}$ & Type of agricultural production & Legal entity \& ownership & Owned rate \\
\hline 11 & Male, $<50$ & 800 & Classic crop production, asparagus production, animal production & $\mathrm{ABC}$ & $50 \%$ owned \\
\hline 12 & Male, $<50$ & 1000 & Organic crop and animal production & $\mathrm{AC}$ & Mostly leased \\
\hline 13 & Male, $>50$ & 1000 & Classic crop production & $\mathrm{AC}$ & Mostly leased \\
\hline 14 & Male, $>50$ & 1400 & Classic crop and animal production, biogas plant & $\mathrm{AC}$ & Mostly leased \\
\hline 15 & Male, $>60$ & 1500 & Classic crop and animal production & $\mathrm{AC} / \mathrm{ABC}$ & Mostly leased \\
\hline 16 & Male, $>50$ & 1580 & Mostly classic crop and animal production & $\mathrm{AC}$ & Mostly leased \\
\hline 17 & Male, $>60$ & 3800 & Organic crop and animal production & $\mathrm{ABC}$ & Mostly leased \\
\hline 18 & Male, $>60$ & 5000 & Classic crop and animal production, wine production & $\mathrm{ABC}$ & Mostly leased \\
\hline 19 & Male, $>50$ & 5500 & Vegetable production & $\mathrm{ABC}$ & Mostly leased \\
\hline
\end{tabular}

$A B C$ agricultural business companies, $A C$ agricultural cooperatives

On the other hand, many farmers considered food and feed production as a priority. Despite that marginal lands are described as lands of poorer soil quality not suitable for agricultural activities, many farmers use them for feed and food production or as meadows and pastures. Some referred to it as "a moral dilemma" as well as incompatible with their farming values and relationship to land, exemplified in the following sentences: "There is something wrong with the world when we in the western part of the world are so selfish that we can say we will grow energy on agricultural land whereas there are other people in different parts of the world who have no food to eat. That is somehow wrong", and, "those who have relationship to land would not grow trees on it." Concerns of food security were raised and some farmers made clear that food security on agricultural land is superior to SRP biomass production, even on marginal lands. The reason why some farmers still engaged in SRP were the higher economic gains from lower quality soils. In general, farmers stated they prefer to engage in other agricultural activities related to food, feed or animal production. However, the reluctance to grow SRP is only partly related to prioritizing food production, as some farmers preferred to grow annual crops for fuel production over SRP.

Another barrier is the fear of losing independency. A hobby farmer considers SRP as a relatively stable crop; however, at the same time, it is not profitable enough to lose his independency by engaging in business with the company. Another farmer explained that by engaging in SRP business with only one business partner he would lose his independency and since he is a part-time, hobby farmer, he is not willing to do so. Especially smaller, private land owners refrain from SRP due to the long-term contracts of at least 10 years. In one case, the landowner requested a higher rent to consent to SRP, which was not agreed to by the farmer. Farmers established SRP either on their own land or on the land leased from Slovak Land Fund, some of them managed to get municipalities' and churches' consent or Urbariat's consent. Urbariat is an association managing mostly forest land but also some agricultural land. The interviews showed that Slovak Land Fund and Urbariats are the most open to SRP. Only a few of the interviewed farmers established SRP on private persons' agricultural land. Land consolidation was highlighted as a crucial aspect that could make growing SRP easier.

Attitudes toward the contract partner, the aim of the project as well as environmental impacts were perceived as important. Among many farmers, a positive attitude toward the contracting partner was observed. Some of the farmers perceive the industry partner as a reliable partner offering clear vision, commitment, sales, and balanced agreement. Positive attitudes were related to the overall corporate philosophy, their design, their aim to produce biomass for themselves and use fast growing natural resources that could compensate other non-renewable resources and agreed to the purpose of SRP.
Table 5 Personal and situational factors (modified after Heckhausen and Heckhausen [49])

\begin{tabular}{ll}
\hline Personal factors & Situational factors \\
\hline $\begin{array}{l}\text { Behavioral tendencies, needs, personalities, habits, } \\
\text { self-images, objectives, emotional preferences, } \\
\text { attitudes, values }\end{array}$ & $\begin{array}{l}\text { Opportunities, stimuli related to positive or negative } \\
\text { outcomes of certain situations, institutional } \\
\text { framework and legal setting, infrastructure, market } \\
\text { situation }\end{array}$ \\
\hline
\end{tabular}


Table 6 Overview of incentives and barriers mentioned by farmers categorized as personal factors

\begin{tabular}{|c|c|c|}
\hline $\begin{array}{l}\text { Personal } \\
\text { factors }\end{array}$ & Incentives & Barriers \\
\hline Values & - use of fallow land & $\begin{array}{l}\text { - incompatible with their farming values and relationship to } \\
\text { land } \\
\text { - do not believe in the purpose of short rotation plantations } \\
\text { - losing independency }\end{array}$ \\
\hline Attitudes & $\begin{array}{l}\text { - positive attitude toward the contracting partner } \\
\text { - purpose of short rotation plantations } \\
\text { - expected positive environmental impacts on soil } \\
\text { - environmental benefits other than beneficial to farmers' agricultural } \\
\text { soil }\end{array}$ & $\begin{array}{l}\text { - negative attitudes toward the contracting partner } \\
\text { - purpose of short rotation plantations } \\
\text { - low confidence in contracting partner } \\
\text { - societal costs } \\
\text { - expected negative environmental impacts }\end{array}$ \\
\hline Self-images & & $\begin{array}{l}\text { - reputation } \\
\text { - responsibility }\end{array}$ \\
\hline Habits & & $\begin{array}{l}\text { - missing experience } \\
\text { - making decisions instinctively }\end{array}$ \\
\hline
\end{tabular}

The fact SRP produces renewables in a short time was perceived rather positively and some farmers positively mentioned the material use of the biomass, as wood from SRP can spare higher wood qualities from forestry. The aspect of the company seeking to become more resource independent by these plantations was positively mentioned by one farmer.

Some farmers also expressed negative attitudes toward the contracting partner. One farmer sees the company as a threat to environment and fears negative impacts of the company's activities on the region in the future. Moreover, another farmer perceives the established plantations as greenwashing only to "look better to the outside world." Two farmers did not believe in the purpose of SRP. They consider it to be only beneficial to the business partner. They feel the material and products from SRP will be of low quality and short life span. Nevertheless, those farmers engaged in SRP due to economic benefits and their interest to try something new, but were worried of soil damage. One farmer only engaged in SRP to prevent the company from asking the land owners he leased the land from, being afraid they might discontinue his lease and lease it to the company instead. Some farmers raised their concerns related to the company's future in Slovakia, which results in a low confidence in the contracting partner. They consider their engagement in SRP as a risky business because they are afraid that the company might not be able to buy the produced SRP biomass at the end of the contracting period. In addition, farmers were afraid that the recultivation of the SRP parcels after 10 or 20 years may not happen, in case the company would decide to shut down its board production site. Farmers are afraid they would then need to take care of the recultivation on their own, resulting in high costs. While expressing these concerns some farmers used examples of multinational companies that had entered the Slovak market for a few years and afterward decided to leave for some other countries, which consequently had some negative impact on
Slovakia and its economy. Related to this, the long-term commitment of 10-20 years is perceived as critical.

Several farmers expected positive environmental impacts on soil from SRP by providing soil recovery, water retention, and nutrients from leaves and roots. For example, several farmers believed SRP can ensure better future yields on converted parcels after the SRP life cycle has been completed. They considered SRP as a more environmentally friendly solution in comparison to conventional agricultural needing high amounts of fertilizers and pesticides. Some farmers noticed environmental benefits not directly beneficial to agricultural soil such as an increase in biodiversity in the surroundings: "The biodiversity increases in the areas where SRP was established. You can spot deer, birds, boars, etc. in those areas. There will be a paradise in 5 years." In this context, farmers also perceived social benefits as a result of environmental benefits. A farmer engaged in SRP in order to separate a landfill from the village, which has been negatively influenced by odor emissions. SRP is therefore expected to improve the living conditions for the village residents. Another farmer engaged in SRP because he found growing trees would benefit society more than growing grass (i.e., producing more oxygen) and expressed his concerns about a decrease of forest cover in Slovakia. By growing SRP he felt he was taking part in restoring it.

On the contrary, expected negative environmental impacts represent a barrier. In general, interviewed farmers had limited knowledge on potential environmental impacts related to SRP and environmental concerns were expressed by both farmers engaged and not engaged in SRP. Farmers expressed concerns about future recultivation of the land, root-system breakdown, potential soil exhaustion, future soil use, and water loss. Some farmers mentioned they are worried whether it will be possible to grow traditional crops afterward. For instance, soil exhaustion and water loss caused by SRP were mentioned by one 
farmer who had some previous experience in growing willows, which damaged the drainage system of his parcel. In addition, fencing needed either prior or after establishing SRP was perceived as a negative aspect causing habitat fragmentation and impacting wildlife rather negatively. One farmer mentioned that he does not feel positive about harvesting and selling the SRP because the soil is being deprived of nutrients and formed humus layer. Farmers who expressed environmental concerns, but nonetheless engaged in SRP did so either because economic aspects overweighed environmental concerns or they were able to recognize also some environmental benefits such as soil recovery and lower need for pesticides and fertilizers. Apart from these aspects, two farmers mentioned gene transfer as a possible threat due to the fact that the poplars are of non-native origin despite them being harvested before bloom. Related to this, societal costs of human health and safety risks due to the non-native origin of planted trees and potential gene transfer were expressed by one farmer. He would have preferred native trees on his parcels if it had been possible.

Being an independent key player on the market was important for farmers' self-image. Farmers said they aim for profit maximization to be taken seriously on the market and be able to sell their production at a reasonable price. In this context, the reputation related to agricultural activities was found to be an important barrier. A farmer highlighted the continuous success of his farm and that his goal is to stay "one of the best farms" in Slovakia winning prizes for cow breeding and wine production, while SRP does not offer these prestigious recognitions.

In addition, farmers had the opinion that someone else should grow SRP. That shows that SRP was not perceived to be their responsibility. A farmer states that bigger farms should engage in SRP (Note: he farms more than 5000 ha). Another farmer, close to "Trnavska tabula" who also has some of the most fertile soils in Slovakia, feels SRP should be grown in less productive regions of Slovakia, such as the more eastern regions because of their lower soil fertility and lower employment. Another farmer suggests that the Slovak State or foresters should engage in SRP instead of farmers.

Among habits, SRP was perceived as new agricultural activity and missing experience acts as another barrier for farmers: "We have not explored this type of agricultural production yet. I am not saying it's not good business at all, however if it was that amazing and profitable all the farmers would have already been producing SRP biomass on their lands." Despite the fact that several farmers did not have much knowledge about SRP, they engaged in it because they gained some knowledge during the meetings with the company. At the same time, some farmers did not have a clear idea on potential benefits or costs of SRP activities, since they did not know anyone already engaged in SRP back then. In one case, the land managers traveled around the region to visit some of the already established SRPs. As the land managers consisted of foresters, not farmers, it was easier for them to become early adopters: "We are foresters, we work with wood on daily basis and so engaging in SRP is the most natural thing for us to do."

Two farmers said that economic aspects are not primary when making decisions but rather they had a habit of making decisions instinctively or emotionally: "It's about the feeling. I have to feel it in there" said the hobby farmer. Another farmer said: "I would have to see deeper meaning to it in order to engage in it... I am guided instinctively when making decisions." It seems however that decisions made with gut instinct are more present when the economic side of the business is already taken care of anyway.

In this study, personal factors related to personal values and habits, such as fear of losing independency, preference for food production and missing experience, were found to overrule the perceived economic benefits and hindered the adoption of SRP. Some farmers aimed for prestige and were interested in other forms of farming such as intensive agricultural practices: "I enjoy other agricultural production more," "we are more interested in the intensive agricultural practices" these are examples showing that despite being financially oriented, farmers can have other interests in which case the potential economic gains are insufficient to engage in SRP. Some farmers required additional incentives such as the perceived environmental and social benefits. Thus, economic benefits alone are not necessarily an incentive for SRP.

\section{Situational Factors Relevant for the Adoption of SRP}

Among the situational factors we found market conditions and the institutional framework and legal setting to be relevant. Table 7 provides an overview of the different factors differentiating them into incentives and barriers.

Regarding market conditions, the economic benefits from marginal lands and required labor input were incentives. However, they also were a barrier as a result of competition with other uses. A prominent incentive observed was the economic benefit from growing SRP on marginal lands, which is related to the use of low-quality soils (sandy, sloppy, acidic, undercultivated or stony soils) resulting in low yields for crops. The Zahorie region is known for its sandy soils and lower productivity when considered for traditional agricultural practices. Many farmers - mostly agricultural cooperativesengaged in SRP to make better use of low-quality soils to increase their profit. They stated that they will make more profits on these marginal lands when compared to their previous agricultural activities and thereby are able to reduce financial losses on other parcels. Similarly, one smaller agricultural business company perceives SRP as a helpful alternative in a business area with generally low economic returns. 
Table 7 Overview of incentives and barriers mentioned by farmers categorized as situational factors

\begin{tabular}{|c|c|c|}
\hline Situational factor & Incentives & Barriers \\
\hline Market conditions & $\begin{array}{l}\text { - Economic benefits from use of low-quality soils } \\
\text { - Low labor input and low amount of chemicals } \\
\text { - Unburdening of employees } \\
\text { - Financial, technical, and administrative support }\end{array}$ & $\begin{array}{l}\text { - Competition with traditional crop production } \\
\text { - Competition with organic and vegetable farming }\end{array}$ \\
\hline Institutional framework and legal setting & & $\begin{array}{l}\text { - Land fragmentation in combination with land } \\
\text { owner's consent } \\
\text { - Close to nature protection areas } \\
\text { - No clear policy }\end{array}$ \\
\hline
\end{tabular}

A crucial aspect related to the economic benefits is the low labor input and low amount of chemicals (fertilizers, pesticides). Hence, SRP was perceived to lower the costs when compared to conventional agricultural practices and therefore allows higher profits. Next to profit, agricultural cooperatives mentioned the unburdening of their employees as an additional incentive, in the form of reduced working hours and easier tasks.

Several farmers positively mentioned the financial, technical, and administrative support the industry partner provided to the farmers by taking care of the measures required to establish SRP. If the industry partner did not take care of it, they would have not considered doing it on their own, as the administrative process was perceived to be too time and energy consuming. Even though farmers did not explicitly discuss the fact that there were no initial investments necessary, one farmer positively mentioned that the company also took care of initial material costs, which made the offer even more profitable to him. In addition, it is positively perceived that no new machinery is needed because the business partner takes care of harvesting.

Nevertheless, farmers said that for them SRP stand in competition with traditional crop production, even on marginal lands. The small economic benefit in comparison to their current agricultural production represents a barrier. For instance, one farmer engaged in vegetable production stated that he must grow as many vegetables as possible on his fields in order to stay competitive. In several cases, marginal lands were used for organic farming. Thus, the competition with organic farming due to low soil quality is a central barrier. As previously mentioned, the Zahorie region has very sandy soils and the agricultural production cannot achieve high yields. Many farmers switched to organic farming after Slovakia entered the European Union in 2004, enabling access to EU subsidies for organic farming. Interviewed farmers involved in organic agriculture claimed that the sandy soils make it impossible to earn profit when farmed conventionally and therefore they decided to start growing crops organically. These sandy soils are suitable for SRP production but because of the environmental subsidies for organic farming, farmers have fewer reasons to engage in SRP. One farmer engaged in
SRP mentioned that the soil quality of their organic production areas is even worse than the soil quality where SRP has been planted.

Regarding institutional framework and legal setting, land fragmentation and lack of clear policy as well as the presence of nature protection areas were barriers. A prominent barrier to engage in SRP is land fragmentation in combination with land owner's consent. It was mentioned by all interviewed farmers engaged in SRP on leased land. The current situation is perceived as an immense obstacle making it very difficult for farmers to engage in SRP. Some farmers reported they were willing to engage in SRP but were not able to: They either held vastly fragmented land with dozens of land owners not suitable to the company's criteria, or the land owners did not provide their consent. In this context, no clear policy represents another barrier. To several farmers, the goal of EU and Slovak policy of alternative sources of energy or material production does not seem straightforward. Some farmers are cautious about engaging in new agricultural activities because the future development of these activities are unclear. For example, farmers are worried whether today's subsidies for SRP will be provided in the future.

Moreover, the being close to nature protection areas was mentioned as an obstacle by one farmer. This farmer reported that he was willing to convert to SRP on several more parcels but since these parcels were located close to Natura 2000 protected area, environmentalists did not allow for this to happen. Thus, he is only engaged in SRP on parcels located further away from Natura 2000 protected area.

We found situational factors, such as market conditions and legal framework, to be substantial barriers for the adoption of SRP. Among the group of farmers not engaged in SRP $(N=9)$, there were three farmers, all from agricultural cooperatives, who would have liked to engage in SRP mostly due to economic benefit (low labor reduces salary costs and need for employees) and, some of these farmers expressed positive environmental impacts of SRP such as waste water treatment and water retention, leaf litter and dead plant material, and better microclimate. However, they either faced obstacles in the form of land fragmentation, landowner's consent or 
unsuitable soils (groundwater level was too low, parcel was too small $<10 \mathrm{ha}$ ). Therefore, not all marginal lands were legally and physically available for SRP production.

In addition, farmers' willingness to adopt SRP was influenced by their legal entity. Agricultural cooperatives felt more responsible toward rural communities and the agricultural land they lease from them. They prioritized SRP over fallow land and positively perceived the economic benefits and low labor input. They were more willing to convert agricultural land to SRP compared to agricultural business companies (all seven interviewed agricultural cooperatives were interested to engage in SRP).

Contrarily, agricultural business companies had to recognize at least one other personal factor to adopt SRP such as perceived environmental benefits or trying something new. In general, agricultural business companies were more profitoriented and SRP profits alone were too little for them to act as incentive. Nevertheless, the majority of farmers engaged in SRP were from agricultural business companies. Interviewed farmers not interested in SRP - mostly agricultural business companies - tended either to concentrate on less "mainstream" agricultural activities, such as vegetable production (e.g., onions, cabbage, asparagus production) to maximize profits. One interviewed farmer mentioned: "Agriculture is a very profitable business. However, if you want to make profit in agriculture, you must not grow what everyone else grows. You must not grow wheat." This highlights the limited financial attractiveness of SRP with regard to the profit orientation of agricultural business companies.

\section{Discussion}

The willingness of farmers to adopt SRP plays an important role for the long-term supply of wood biomass. Considering farmers as entrepreneurs who decide to invest their assets (e.g., land and labor) in a new farming practice, they can be referred to as early adopters in the process of innovation diffusion [48]. Assuming that farmers' willingness to adopt SRP is driven by their motivation to act in a certain way, this study identified and described relevant personal and situational factors [49]. These factors have been differentiated into incentives and barriers depending on whether the facilitated or hindered farmers willingness to adopt SRP. Note, personal and situational factors should not be viewed in isolation from each other [49]. The identified factors (e.g., market conditions, values) are closely linked with each other and are interpreted differently by the farmers. In the following paragraphs, the identified factors will be discussed in context of the existing literature, as well as theories and models used.

Farmers engaged in SRP because of personal factors such as their attitudes and values (i.e., use fallow land, try something new, crop diversification, expected positive environmental impacts). Agricultural business companies had to recognize environmental benefits or wanted to try something new. For them the situational factor market condition was not incentivizing because their existing agricultural production was more profitable than SRP. This is in agreement with existing literature that expected economic benefits only play a limited role in the adoption of new agricultural practices [2] and contributes to the finding that profit is necessary but not sufficient [27]. However, economic benefits were also found to outweigh barriers related to attitudes and values such as expected negative environmental impacts and preference for food production.

The personal relationship to land and agriculture influences farmers' willingness to grow SRP, as by some it is not considered compatible with their values and identity as a farmer. This can be explained with farmers' role of generating symbolic capital from agriculture as being a "good" farmer generates approval by their peers [61]. Similarly, literature on landscape valorization shows that food production is perceived as the main element of creating value from agriculture [62]. Therefore, it is necessary to strengthen the perceived value that is being generated with SRP. In addition, especially the long binding to certain plants (permanent crops) or contracting parties turned out to be crucial for the farmers' willingness to adopt SRP, which hardly fit in with the tradition of agriculture.

The study suggests that SRP can strengthen farmers' identity when growing SRP instead of having fallow land. This can be explained with the weak income and problem of land abandonment [52] in rural regions in Eastern Europe. Agricultural cooperatives preferred SRP over fallow land because they felt bigger responsibility for the rural community they are based in and to maintain traditions. In both cases (preferring food over SRP, preferring SRP over fallow land), social norms in combination with socio-cultural identity (i.e., what is expected by farmers within a community) are central issues.

That farmers prefer to engage in food production over SRP and do not want to consider themselves as foresters is a wellknown barrier [27], also present in this study on marginal lands. The decision to engage in SRP is defined by how the farmers themselves personally define and perceive the land and its quality rather whether the land is officially labeled as marginal. In several cases, farmers do not consider their land "marginal enough" to grow SRP. This phenomenon was reported in a recent study on energy crops arguing that this is related to farmers taking pride in their land [63].

Another factor was the perceived range of responsibility. People only take action (e.g., to solve an environmental problem) if they attribute some responsibility to themselves [64]. To increase the level of responsibility, it can make sense to inform the farmers about how they can contribute to cover the increasing demand of biomass as projected in the vision of a bioeconomy. Literature [65] shows that incentives for the 
sustainable management of natural resources and the preservation of ecosystems can be successful above all, if benefits are perceived that are not directly linked to agriculture (e.g., social or environmental benefits). However, the purpose of producing SRP biomass was perceived ambiguously. Some farmers believe that SRP can spare higher wood qualities, whereas others considered the SRP biomass to be of low quality and of little use for the community. Although socioeconomic benefits are a key incentive for local communities to be involved in new technologies such as renewable energy $[66,67]$ and local production and processing of SRP biomass can contribute to rural value creation (e.g., planting, tending, harvesting), this was not perceived by the famers. Willingness to grow SRP can be undermined by concerns about expected risk to health and quality of life [68], especially from the use of transgenics [22]. Currently, the consent of the environmental authority is needed for planting non-native species of poplars. As there are worries about the potential hybridization of nonindigenous poplar hybrids with the indigenous black poplar, the project investigated the potential effect of our plantations not only on biodiversity but also on the indigenous genetic material that is present in Slovakia. The preliminary results of our research show that the plantations pose no risk to the indigenous populations, as the low likelihood of hybridization is excluded by the early timing of harvest (after 4th and 6th vegetation season), which is before the poplars reach their maturity, thus they cannot produce reproductive material. Therefore, communicating the impacts SRP has on the society and environment (e.g., reduced emissions from local production of feedstock, reduced harvesting pressure on forests, rural income from local production, reducing import dependency) may contribute to a more positive perception among farmers and other local stakeholders. The benefit of SRP perceived overall in terms of its contribution to a bioeconomy can relate to farmers' general level of environmental awareness, as this was found to be relevant for farmers' perception of frameworks aimed to foster bioeconomy [69].

Among the situational factors, economic benefits from using low-quality soils played an incentivizing role. The economic benefits gained from SRP were found to be of little relevance for farmers of the more profit oriented agricultural business companies. This is supported by literature that economics matter and land owners are unwilling to adopt bioenergy crops unless there is a significant improvement in market outlook and profitability [42]. This was specifically the case for the agricultural business companies, which were more interested in agricultural options that will generate higher income than SRP does (e.g., intensive agricultural practice or less common commodities on the market such as vegetables).

Scientific literature reports that the limited attractiveness of SRP is caused by financial risks. High initial investment costs, low economic returns, and poor cash flow prevent farmers from converting their land to SRP [32]. In the case of
Hungary, the lack of administrative capacity, combined with the excessively long processing times of subsidy applications, led to financial risks and thus negatively impacted farmers' willingness to adopt SRP [70]. Our study shows that the aspect of financial risk is limited in the project area, due to the contract not requiring additional investments in machinery as the industry partner is taking over those investments and buying the produced feedstock.

Farmers perceive the long-term contracts offered by a single company as risky because the company might not be able to conduct the expensive re-cultivation or buy the biomass since they might have financial problems in the future and shut down their production site. This can be explained with negative attitudes toward the contracting partner and some general skepticism against multi-national companies in Eastern European countries. Whether SRP was perceived as risky, partly depended on farmers' attitudes toward the contracting partner. Some farmers had a positive attitude toward the contracting partner and valued the business opportunity, whereas other farmers had little trust in the contracting partner and rated the financial risk higher. These findings add to the technology acceptance framework [50] in which trust affects several other factors such as perceived costs, risks or benefits, which in turn affects the general attitude. For other renewable technologies (e.g., wind energy), confidence in the actors involved has proven to be an important situational factor for acceptance [71, 72]. This underlines the premise that not a situation in an objective sense influences behavior, it is more about how a specific person interprets this situation [49].

Land fragmentation and the necessity to get landowner's consent and lack of clear policy were found to be prominent situational barriers, related to the legal and agricultural structure in Slovakia. Marginal land can belong to dozens of land owners, which makes it very challenging to get their approval and therefore excludes a large share of agricultural area. Required land owner consent can hinder farmers' engagement in SRP despite their willingness to adopt SRP. This makes the situation in Slovakia very specific in comparison to neighboring countries where such a prerequisite does not exist. To promote SRP, an enabling environment-i.e., change of existing legal provisions - is needed. Land consolidation is a further conducive aspect that could contribute to higher adoption of SRP. In addition, administrative and legal help is offered by the industry partner. This suggests that if the industry partner reduced the situational barriers (market-risk, legal), farmers willingness to adopt can be increased. This finding adds to the literature about the importance of developing and promoting SRP in terms of reducing its uncertainty associated with its economic viability [32] and the negative impacts of unfavorable institutional conditions such as too complex legislation, a lack of administrative capacity, and fragmentation of responsibilities [73]. To reach the climate change mitigation goals of the EU, we would recommend that a unified clear 
legal framework should be established on the European level to help to overcome these regional political constraints.

The study shows that land use competition is an issue even on marginal lands. SRP stands in competition with agricultural activities related to food production. That marginal lands can be scarce for economical reasons, while being physically abundant, has been pointed out before [31], and the economic supply depends on the opportunity costs associated with existing activities, the riskiness and costly reversibility of investments, and possible disamenities from changed land use. This is also true for our study. We expect no competition for marginal land to be placed on steeper slopes, which is difficult to approach with heavy machinery and as a result not used for annual crop production. However, areas with slopes steeper than $10 \%$ are described as not suitable for establishment of larger SRPs with automated planting and harvesting practices [74]. Nonetheless, smaller SRP with motor-manual planting and harvesting practices can be established on steeper slopes.

The dissusion of innovation theory [48] provides criteria to structure and discuss farmers' responses as done in previous studies $[27,75]$ showing that farmers are cautious when it comes to being "early adopters" [27], especially if observability and trialability is not given. Interpreting the results in context of the innovation diffusion theory $[48,75]$, farmers partly perceived the relative advantage of SRP (workload and environment). In some cases, SRP was compatible with existing practices, values, and needs (trying something new, unburdening workers, using fallow land). In other cases, SRP was not compatible because it was against their values (prioritization of food production, profit orientation, reputation). Complexity was perceived as low due to the legal, administrative, and harvesting assistance provided by the company. Trialability is not given because this management form requires a 10-year minimum contract. Observability, which is important for farmers, is only given to a small extent because there are only a few farmers. Risk is partly perceived to be minimized through the company contracts. However, farmers still perceive it to be risky because the contracts are for 20 years and with an international company.

Although this study focused on SRP on marginal land, we found that in many cases the barriers and incentives indentified for SRP on regular agricultural land were also true for marginal land such as the competition of SRP with other agricultural production and expected negative impacts on soil [21, 39, 43, 45]. Interestingly, these two main benefits commonly communicated to support SRP on marginal soil were not perceived by all farmers.

Our study suggests that there are different farmer types with different motives to engage in agricultural practices. Thus, farmers' attitudes and behavior toward the sustainable production of SRP could be addressed in future research with the aim to differentiate their willingness to grow SRP by different farmer types (e.g., economically or environmentally motivated) [76]. This could also provide better information on which farmers act as "early adopters" under which conditions. Moreover, several studies also showed that the visual appearance and the type of landscape play a major role in the acceptance of SRP by the local residents. A study shows [77] for example, that the establishment of SRP in small-structured agricultural landscapes is predominantly viewed negatively. The situation is quite different in open arable landscapes. There, the integration of SRP is more seen as a kind of landscape diversification and thus assessed positively. They [77] also stated that kind of tree species (e.g., poplar, willow, robinia) and the distance between the plantation and the path or its design (e.g., with flower strips) also makes a difference in acceptance. Another study [78] shows that most people would accept the plantations even within sight of their place of residence as long as the biomass power plant is not visible. This shows that acceptance of SRP itself is far different from those of associated infrastructure (e.g., power plant, machine paths). However, while this study did not identify visual appearance as an influencing factor, these sensitivities must be carefully considered in future research. Because land owners have a central role in the adoption of SRP, future research should investigate land owners' attitudes toward SRP, as was done for willows for biofuel production [79]. Demonstrating and communicating the economic viability of SRP crops and environmental benefits (e.g., soil preservation, ecosystem services) could be beneficial to increase land owners' acceptance [79]. Another interesting question is how local residents perceive the plantations [80], as for intensive forestry, public acceptance was low for clone cultivation [81], presenting a potential conflict for the non-native species used for SRP poplar, and non-traditional agricultural practices received only limited acceptance by residents [25].

\section{Conclusion}

Farmers' willingness to adopt SRP on marginal lands is a prerequisite to realize their potential in supplying biomass and rural income. This exploratory study investigated personal and situational factors relevant to farmers' willingness with the help of qualitative interviews.

This study identified a variety of factors that can have an incentivizing or hindering impact on farmers' willingness to adopt SRP. Among the personal factors, attitudes, values, selfimage, and habits related to farming were of relevance. Among the situational factors, the market situations, legal and instructional setting, and available infrastructure were identified. Several of the described factors were also reported in the literature. Therefore, the incentives and barriers identified in the literature largely also applied to the case of marginal lands. 
The study adds to existing literature by the following findings. We observed uncertainty among farmers on how SRP impacts the environment, specifically on the soil. In addition, attitudes toward the contracting party played a role in how far farmers considered SRP to be a risky business. A reason might be that SRP is a new agricultural practice in Slovakia. Despite that SRP on marginal lands is not considered to be in competition with food production, this was not the case. Several farmers preferred to grow food over SRP on their marginal land. Farmers have difficulties identifying with SRP on agricultural land. However, agricultural cooperatives are more involved in rural communities and prioritize production over leaving land fallow. We suggest that SRP can strengthen the identity of farmers, as they prefer SRP over fallow land. The study shows that agricultural cooperatives tend to be more open to SRP in comparison to agricultural business companies, as they perceive the economic benefits more positively. Agricultural businesses had to recognize more than economic benefits to be willing to grow SRP. Agricultural business companies are more profit-oriented when compared to agricultural cooperatives and prefer to engage in agricultural practices, generating higher income (e.g., vegetables, organic farming). Last but not least, land fragmentation in Slovakia in combination with the obligatory landowner's consent represents an important situational barrier. Therefore, land consolidation is a crucial aspect that could increase farmers willingness to adopt SRP.

This study is based on a limited number of semi-structured interviews. Thus, the qualitative research design does not allow generalizing the results. Instead, it provides an in-depth view into the spectrum of farmers' motivations to engage in SRP and influencing structures. Moreover, the results of this study are based on farmers' experience and perceptions. Thus, the identified incentives and barriers are only covered from a personal and/ or farm-level perspective and some of them are specific to Slovakia. However, to provide empirical evidence that these factors are specific to Slovakia, a comparative study is needed.

Future research should investigate other countries but also regions in Slovakia (e.g., with higher rates of unemployment) or which contracts are the most attractive (e.g., with choice experiments) for which farm types. However, as economic benefits were not sufficient to persuade farmers to engage in SRP, future research should focus on the role of other factors than those related to the market situation, such as environmental and social benefits derived from SRP.

From a practical perspective, we suggest the following measures to support farmers' willingness to adopt SRP on marginal lands, which address personal and situational factors that are relevant to the farmers. Farmers and relevant stakeholders (land owners, policy makers, authorities, general public) should be provided with science-based facts about the possible impacts of SRP on soil and the environment, since the study identified conflicting views on such aspects (e.g., nutrient deprivation, root system damage, difficult cultivation, gene transfer and habitat fragmentation were mentioned as risks). As the study shows that agricultural cooperatives tend to be more open to SRP in comparison to agricultural business companies, they could be specifically targeted to strengthen their identity as farmers (e.g., some agricultural activity instead of having fallow land was preferred). As there is a lack of trialability, observability, and tradition of SRP, best practice results should be demonstrated and communicated to the farmer community. To reach the climate change mitigation goals of the EU, a unified clear legal framework and consistent policies should be established on the European level to help to overcome regional political constraints and to enhance the farmers' SRP operation security (i.e., no obligatory land owner consent, land consolidation, subsidies, tax incentives, technical and financial assistance). Note, any policy which requires farmers to adopt innovative practices is unlikely to succeed without taking full account of their motivations and socio-cultural characteristics, and how these influence their decision-making, as perspectives and goals between farmers and policy makers can differ significantly. Therefore, these policies should be codeveloped with actors and stakeholders involved.

Funding This study received funding from the Bio Based Industries Joint Undertaking under the European Union's Horizon 2020 research and innovation programme under grant agreement No 745874 and the Austrian Research Promotion Agency (FFG) under the COMET program Grant Number 865905 . Open access funding provided by University of Natural Resources and Life Sciences Vienna (BOKU).

Data Availability Not available.

\section{Compliance with Ethical Standards}

Conflicts of Interest The authors declare that they have no conflict of interest.

Code Availability (Software Application or Custom Code) Not available.

Open Access This article is licensed under a Creative Commons Attribution 4.0 International License, which permits use, sharing, adaptation, distribution and reproduction in any medium or format, as long as you give appropriate credit to the original author(s) and the source, provide a link to the Creative Commons licence, and indicate if changes were made. The images or other third party material in this article are included in the article's Creative Commons licence, unless indicated otherwise in a credit line to the material. If material is not included in the article's Creative Commons licence and your intended use is not permitted by statutory regulation or exceeds the permitted use, you will need to obtain permission directly from the copyright holder. To view a copy of this licence, visit http://creativecommons.org/licenses/by/4.0/.

\section{References}

1. European Commission (2012) Innovating for sustainable growth: a bioeconomy for Europe, Communication from the Commission to the European Parliament, the Council, the European Economic and 
Social Committee and the Committee of the Regions. European Commission, Brussels

2. Convery I, Robson D, Ottitsch A, Long M (2012) The willingness of farmers to engage with bioenergy and woody biomass production: a regional case study from Cumbria. Energy Policy 40(Supplement C):293-300

3. European Commission (2018) Communication from the Commission to the European Parliament, the Council, The European Economic and Social Committee and the Committee of the Regions a sustainable bioeconomy for Europe: strengthening the connection between economy, society and the environment COM/2018/673 final. European Commission, Brussels

4. Näyhä A, Hetemäki L, Stern T (2014) New products outlook. In: Hetemäki L (ed) What science can tell us 6. European Forest Institute, Joensuu, pp 43-54

5. Thrän D, Edel M, Seidenberger T (2009) Identifizierung strategischer Hemmnisse und Entwicklung von Lösungsansätzen zur Reduzierung der Nutzungskonkurrenzen beim weiteren Ausbau der energetischen Biomassenutzung - 1st Status report. Deutsches Biomasseforschungszentrum, Leipzig

6. Mantau U, Saal U, Prins K, Steierer F, Lindner M, Verkerk H, Eggers J, Leek N, Oldenburger J, Asikainen A (2010) EUwoodreal potential for changes in growth and use of EU forests. Final report. University of Hamburg, p 160

7. Lindegaard KN, Adams PWR, Holley M, Lamley A, Henriksson A, Larsson S, von Engelbrechten H-G, Esteban Lopez G, Pisarek M (2016) Short rotation plantations policy history in Europe: lessons from the past and recommendations for the future. Food Energy Secur 5(3):125-152

8. Pöyry (2017) Who needs more plantations?, Pöyry Management Consulting Oy CAETS 2018, Montevideo, Uruguay

9. Bemmann A, Schweinle J (2015) The implementation of scientific research findings in policy making: challenges and contradictions highlighted by the example of short rotation coppice. Bioenergy from dendromass for the sustainable development of rural areas. Wiley-WCH, Weinheim, pp 507-526

10. Wilhelm E-G, Nych F, Schmidt PA, Winter S (2015) Synergies and conflicts between an increasingly widespread cultivation of short rotation coppice and nature conservation at the landscape level. Bioenergy from dendromass for the sustainable development of rural areas. Wiley-WCH, Weinheim, p 17

11. Isebrands JG, Richardson J (2015) Poplar and willow: trees for society and the environment. Food and Agriculture Organization of the United Nations (FAO). http://www.fao.org/documents/card/ en/c/c4d9d4e1-ebd7-4a9b-aed0-05159fd223b5/

12. Rockwood D, Naidu C, Carter D, Rahmani M, Spriggs T, Lin C, Alker G, Isebrands J, Segrest S (2004) Short-rotation woody crops and phytoremediation: opportunities for agroforestry? New vistas in agroforestry. Springer, Dordrecht, pp 51-63

13. Styles D, Börjesson P, d'Hertefeldt T, Birkhofer K, Dauber J, Adams P, Patil S, Pagella T, Pettersson LB, Peck P (2016) Climate regulation, energy provisioning and water purification: quantifying ecosystem service delivery of bioenergy willow grown on riparian buffer zones using life cycle assessment. Ambio 45(8): 872-884

14. Langeveld H, Quist-Wessel F, Dimitriou I, Aronsson P, Baum C, Schulz U, Bolte A, Baum S, Köhn J, Weih M, Gruss H, Leinweber P, Lamersdorf N, Schmidt-Walter P, Berndes G (2012) Assessing environmental impacts of short rotation coppice (SRC) expansion: model definition and preliminary results. BioEnergy Res 5(3):621635

15. European Commission (2017) Report from the Commission to the European Parliament and the Council on the implementation of the ecological focus area obligation under the green direct payment scheme COM/2017/0152 final. European Commission, Brussels
16. Bastin J-F, Finegold Y, Garcia C, Mollicone D, Rezende M, Routh D, Zohner CM, Crowther TW (2019) The global tree restoration potential. Science 365(6448):76

17. Beer L, Theuvsen L (2019) Conventional German farmers' attitudes towards agricultural wood and their willingness to plant an alley cropping system as an ecological focus area: a cluster analysis. Biomass Bioenergy 125:63-69

18. OECD (2001) Glossary of statistical terms. https://stats.oecd.org/ glossary/download.asp

19. Wolbert-Haverkamp M, Musshoff O (2014) Are short rotation coppices an economically interesting form of land use? A real options analysis. Land Use Policy 38:163-174

20. Morris W, Henley A, Dowell D (2017) Farm diversification, entrepreneurship and technology adoption: analysis of upland farmers in Wales. J Rural Stud 53:132-143

21. Abolina E, Luzadis VA (2015) Abandoned agricultural land and its potential for short rotation woody crops in Latvia. Land Use Policy 49:435-445

22. Wegener DT, Kelly JR (2008) Social psychological dimensions of bioenergy development and public acceptance. BioEnergy Res 1(2):107-117

23. Lewandowski I (2018) Bioeconomy: shaping the transition to a sustainable, biobased economy. Springer, Cham

24. Wüstenhagen R, Wolsink M, Bürer MJ (2007) Social acceptance of renewable energy innovation: an introduction to the concept. Energy Policy 35(5):2683-2691

25. Williams K (2011) Relative acceptance of traditional and nontraditional rural land uses: views of residents in two regions, southern Australia. Landsc Urban Plan 103(1):55-63

26. Marron N, Beimgraben T, De Berg L, Brod-Deck F, Eltrop L, Focke J, Haid S, Haerdtlein M, Nahm N, Pelz S (2012) Cost reduction and efficiency improvement of short rotation coppice. CCREF Final Report, Champenoux

27. Warren CR, Burton R, Buchanan O, Birnie RV (2016) Limited adoption of short rotation coppice: the role of farmers' sociocultural identity in influencing practice. J Rural Stud 45:175-183

28. Tubby I, Armstrong A (2002) Establishment and management of short rotation coppice, practice note (7 (revised)). Great Britain Forestry Commission

29. Busse M, Siebert R (2018) Acceptance studies in the field of land use - a critical and systematic review to advance the conceptualization of acceptance and acceptability. Land Use Policy 76:235245

30. Zyadin A, Natarajan K, Igliński B, Iglińska A, Kaczmarek A, Kajdanek J, Pappinen A, Pelkonen P (2017) Farmers' willingness to supply biomass for energy generation: evidence from South and Central Poland. Biofuels 8(4):421-430

31. Barham BL, Mooney DF, Swinton SM (2016) Inconvenient truths about landowner (un)willingness to grow dedicated bioenergy crops, choices. Quarter 4. http://www.choicesmagazine.org/ choices-magazine/submitted-articles/inconvenient-truths-aboutlandowner-unwillingness-to-grow-dedicated-bioenergy-crops

32. Parra-López C, Holley M, Lindegaard K, Sayadi S, Esteban-López G, Durán-Zuazo VH, Knauer C, Engelbrechten H, Winterber R, Henriksson A, Lamley A, Nylander A, Paulrud S, Leonard P, Daly P, Drzewaszewski L, Rzewuski W (2017) Strengthening the development of the short-rotation plantations bioenergy sector: policy insights from six European countries. Renew Energy 114(Part B):781-793

33. Schweier J, Becker G (2013) Economics of poplar short rotation coppice plantations on marginal land in Germany. Biomass Bioenergy 59:494-502

34. Colombo SJ, Jiaxin C, Ter-Mikaelian MT, Heath LS (2008) Future carbon storage in harvested wood products from Ontario's crown forests. Can J For Res 38(7):1947-1958 
35. Ajzen I, Fishbein M (2005) The influence of attitudes on behavior. In: Albarracin D, Johnson BT, Zanna MP (eds) The handbook of attitudes. Erlbaum, Mahwah, pp 173-221

36. Kruse M (2011) In: Godemann J, Michelsen G (eds) Sustainability communication. Springer, Berlin

37. Glithero NJ, Wilson P, Ramsden SJ (2013) Prospects for arable farm uptake of short rotation coppice willow and miscanthus in England. Appl Energy 107(Supplement C):209-218

38. Berndes G, Bird N, Cowie A (2011) Bioenergy, land use change and climate change mitigation. Background Technical Report, IEA Bioenergy. https://www.ieabioenergy.com/blog/publications/ bioenergy-land-use-change-and-climate-change-mitigation-background-technical-report/

39. Ābolina E, Luzadis VA, Lazdina D (2014) Analysis of the adoption of willow growing practice in Latvia. Balt For 20(1):78-87

40. Rowe RL, Street NR, Taylor G (2009) Identifying potential environmental impacts of large-scale deployment of dedicated bioenergy crops in the UK. Renew Sust Energ Rev 13(1):271-290

41. Pretzsch J, Skodawessely C (2010) Sozio-ökonomische und ethische Aspekte der Kurzumtriebswirtschaft. AGROWOOD Kurzumtriebsplantagen in Deutschland und Europäische Perspektiven. Weißensee, Berlin, pp 230-242

42. Spiegel A, Britz W, Djanibekov U, Finger R (2018) Policy analysis of perennial energy crop cultivation at the farm level: short rotation coppice (SRC) in Germany. Biomass Bioenergy 110:41-56

43. Schulze J, Gawel E, Nolzen H, Weise H, Frank K (2017) The expansion of short rotation forestry: characterization of determinants with an agent-based land use model. GCB Bioenergy 9(6): $1042-1056$

44. Parra-López C, Sayadi-Gmada S, Durán-Zuazo VH (2015) Production and use of biomass from short-rotation plantations in Andalusia, southern Spain: limitations and opportunities. New Medit 14(3):40-49

45. Sims REH, Maiava TG, Bullock BT (2001) Short rotation coppice tree species selection for woody biomass production in New Zealand. Biomass Bioenergy 20(5):329-335

46. Bergtold JS, Fewell J, Williams J (2014) Farmers' willingness to produce alternative cellulosic biofuel feedstocks under contract in Kansas using stated choice experiments. BioEnergy Res 7(3):876884

47. Palm-Forster LH, Swinton SM, Shupp RS (2017) Farmer preferences for conservation incentives that promote voluntary phosphorus abatement in agricultural watersheds. J Soil Water Conserv 72(5):493-505

48. Rogers EM (1995) Diffusion of innovations. The Free Press, New York

49. Heckhausen J, Heckhausen H (2018) Motivation and action: introduction and overview. Motivation and action. Springer, Cham, pp $1-14$

50. Huijts NMA, Molin EJE, Steg L (2012) Psychological factors influencing sustainable energy technology acceptance: a reviewbased comprehensive framework. Renew Sust Energ Rev 16(1): $525-531$

51. Serenčéš P, Tóth $M$ (2012) Zhodnotenie tvorby a rozdelenia pridanej hodnoty $\mathrm{v}$ pol'nohospodárstve Slovenska: evaluation of creation and distribution of added value in Slovak agriculture. In: Global commodity markets: new challenges and the role of policy: International Scientific Days 2012 : proceedings = Globálne komoditné trhy: nové výzvy a úloha verejných politík : Medzinárodné vedecké dni 2012 : zborník recenzovaných príspevkov z medzinárodnej vedeckej konferencie, 16-18 máj, Nitra, p 473-482

52. Lieskovský J, Bezák P, Špulerová J, Lieskovský T, Koleda P, Dobrovodská M, Bürgi M, Gimmi U (2015) The abandonment of traditional agricultural landscape in Slovakia - analysis of extent and driving forces. J Rural Stud 37:75-84
53. Green Report (2015) Report on agriculture and food industry in the Slovak Republic for 2014, Green Report. Ministry of agriculture and rural development of the Slovak Republic. http://www.mpsr.sk/ en/index.php?navID=1\&id=45

54. Vozárová IK, Kotulic R, Vavrek R (2016) Legal form as a determinant of the evaluation of agricultural entities in Slovakia using the topsis method. J Environ Manag Tour 7(2):348-356

55. Kristiánová K, Adamková J (2010) Slovak agricultural landscapetransition responses. AZ ITU J Fac Archit 7(2):121-132

56. Bandlerova A, Marisova E (2003) Importance of ownership and lease of agricultural land in Slovakia in the pre-accession period. Agric Econ 49(5):213-216

57. Bandlerová A, Marišová E, Schwarcz P (2011) Ownership and use relationships to agricultural land in Slovakia after the EU accession. Department of Law, FESRD, SUA NITRA. Available under: https://api.semanticscholar.org/CorpusID:203614881

58. Leibing C, Sebastova A, Molitoris L (2019) D1.1 agreements with land owners and land users. Dendromass4Europe - project report. https://www.dendromass4europe.eu/

59. Lamnek S, Krell C (2011) Qualitative sozialforschung. Beltz, Weinheim

60. Némethová J, Civáň M (2017) Regional differences in agriculture in Slovakia after its accession to the European Union. Quaest Geogr 36(2):9-21

61. Burton RJF, Kuczera C, Schwarz G (2008) Exploring farmers' cultural resistance to voluntary agri-environmental schemes. Sociol Rural 48(1):16-37

62. Schaller L, Targetti S, Villanueva AJ, Zasada I, Kantelhardt J, Arriaza M, Bal T, Fedrigotti VB, Giray FH, Häfner K, Majewski E, Malak-Rawlikowska A, Nikolov D, Paoli J-C, Piorr A, Rodríguez-Entrena M, Ungaro F, Verburg PH, van Zanten B, Viaggi D (2018) Agricultural landscapes, ecosystem services and regional competitiveness - assessing drivers and mechanisms in nine European case study areas. Land Use Policy 76:735-745

63. Helliwell R (2018) Where did the marginal land go? Farmers perspectives on marginal land and its implications for adoption of dedicated energy crops. Energy Policy 117:166-172

64. Hines JM, Hungerford HR, Tomera AN (1987) Analysis and synthesis of research on responsible environmental behavior: a metaanalysis. J Environ Educ 18(2):1-8

65. European Commission (2013) The reform of the cap towards 2020. Consultation document for impact assessment. European Commission, Brussels

66. Heinbach K, Aretz A, Hirschl B, Prahl A, Salecki S (2014) Renewable energies and their impact on local value added and employment. Energy Sustain Soc 4(1): 1

67. Rossi AM, Hinrichs CC (2011) Hope and skepticism: farmer and local community views on the socio-economic benefits of agricultural bioenergy. Biomass Bioenergy 35(4):1418-1428

68. Prosperi M, Lombardi M, Spada A (2019) Ex ante assessment of social acceptance of small-scale agro-energy system: a case study in southern Italy. Energy Policy 124:346-354

69. Wensing J, Carraresi L, Bröring S (2019) Do pro-environmental values, beliefs and norms drive farmers' interest in novel practices fostering the bioeconomy? J Environ Manag 232:858-867

70. Wróbel A, Mosiej J, Weith M (2009) Land availability analysis and social attitude aspects in relation to implementation and development of short' rotation forestry systems in Poland. Ann Warsaw Univ Life Sci-SGGW Land Reclam 41(2):153-166

71. Corscadden K, Wile A, Yiridoe E (2012) Social license and consultation criteria for community wind projects. Renew Energy 44: 392-397

72. Jones CR, Eiser JR (2009) Identifying predictors of attitudes towards local onshore wind development with reference to an English case study. Energy Policy 37(11):4604-4614 
73. Agterbosch S, Meertens RM, Vermeulen WJ (2009) The relative importance of social and institutional conditions in the planning of wind power projects. Renew Sust Energ Rev 13(2):393-405

74. Dimitriou I, Rutz D (2015) Sustainable short rotation coppice: a handbook. WIP Renewable Energies, Munich

75. White SS, Brown CJ, Gibson JW, Hanley E, Earnhart DH (2009) Planting food or fuel: developing an interdisciplinary approach to understanding the role of culture in farmers' decisions to grow second-generation, biofuel feedstock crops. Comp Technol Transf Soc 7(3):287-302

76. Walder P, Kantelhardt J (2018) The environmental behaviour of farmers - capturing the diversity of perspectives with a Q methodological approach. Ecol Econ 143:55-63

77. Boll JT (2016) Auswirkungen des Dendromasseanbaus in Kurzumtriebsplantagen auf die ästhetische Qualität und die Erholungseignung der Landschaft. Dissertation, Gottfried Wilhelm Leibniz Universität Hannover
78. Dockerty T, Appleton K, Lovett A (2012) Public opinion on energy crops in the landscape: considerations for the expansion of renewable energy from biomass. J Environ Plan Manag 55(9):1134-1158

79. Gowan CH, Kar SP, Townsend PA (2018) Landowners' perceptions of and interest in bioenergy crops: exploring challenges and opportunities for growing poplar for bioenergy. Biomass Bioenergy 110:57-62

80. Rollins CL, Boxall PC, Luckert MK (2015) Public preferences for planting genetically improved poplars on public land for biofuel production in western Canada. Can J For Res 45(12):1785-1794

81. Hemström K, Mahapatra K, Gustavsson L (2014) Public perceptions and acceptance of intensive forestry in Sweden. Ambio 43(2): 196-206

Publisher's Note Springer Nature remains neutral with regard to jurisdictional claims in published maps and institutional affiliations. 